\title{
Sedimentology of a coastal shelf sector characterised by multiple bedload boundaries: Plettenberg Bay, inner Agulhas Bank, South Africa
}

\author{
Burg Flemming $^{1}\left(\mathbb{D} \cdot\right.$ Keith Martin $^{2}$
}

Received: 30 November 2020 / Accepted: 17 May 2021 / Published online: 6 July 2021

(c) The Author(s) 2021

\begin{abstract}
The study deals with a large sand body (spit-bar) attached to the eastern tip of the Robberg Peninsula, Plettenberg Bay, South Africa. To date, the bar has prograded about $8 \mathrm{~km}$ beyond the tip of the peninsula. The bar top is predominantly composed of medium sand, the upper slope of fine sand, and the lower slope of fine muddy sand. Stratigraphically, the sedimentology thus documents an upward coarsening, calcareous quartz-arenitic depositional sequence. The spit-bar as a whole forms the eastern end of a sediment compartment that is clearly distinguishable from neighbouring compartments on the basis of its geomorphology, the textural characteristics of the sediment, and the distribution of sediment thicknesses. Aeolian overpass across the peninsula appears to have formed a fan-like sand deposit in its rear, which is perched upon the upper shoreface of the bay as suggested by the bathymetry to the north of the peninsula. It forms an integral part of the sediment body defining the spit-bar. The estimated volume of sand stored in the spit-bar amounts to $5.815 \mathrm{~km}^{3}$, of which $0.22 \mathrm{~km}^{3}$ is contributed by the aeolian overpass sand. The sediment sources of the spit-bar are located up to $100 \mathrm{~km}$ to the west, where a number of small rivers supply limited amounts of sediment to the sea and numerous coastal aeolianite ridges in the Wilderness embayment have been subject to erosion after becoming drowned in the course of the postglacial sea-level rise since about $12 \mathrm{ky}$ BP. By contrast, the sediment volume in the adjacent compartment B to the north (Plettenberg Bay), which has been supplied by local rivers, amounts to only $0.127 \mathrm{~km}^{3}$. In a geological context, large sand bodies such as the Robberg spit-bar are excellent exploration models for hydrocarbons (oil and gas).
\end{abstract}

\section{Introduction}

Headland-attached sand bodies are commonly associated with wind- and swell-driven currents that move sand alongshore until an obstacle, usually in the form of a rocky headland, either prevents or inhibits further transport. In cases where further transport is prevented, all the sediment becomes trapped in large sand bodies attached to the headlands, whereas in others, some of the sand manages

This article is part of the Topical Collection on Coastal and marine geology in Southern Africa: alluvial to abyssal and everything in between

Burg Flemming

bflemming@senckenberg.de

1 Senckenberg Forschungsinstitut und Naturmuseum Frankfurt, Senckenberganlage 25, 60325 Frankfurt am Main, Germany

2 Alcobendas, Spain to bypass or overpass (by aeolian transport) the headland to continue the alongshore journey. Well-documented case studies are, amongst others, known from Australia (e.g. Field and Roy 1984; Ferland 1990; Roy et al. 1994; Goodwin et al. 2013), South Africa (e.g. Birch 1980; Martin and Flemming 1986; McLachlan et al. 1994; Flemming 1998), Brazil (e.g. Mendoza et al. 2014; Vieira da Silva et al. 2016, 2018), and California (e.g. George et al. 2018). General overviews and modelling studies of headland bypassing and overpassing processes have been provided by Guillou and Chapalain (2011), Ribeiro (2017), Short (2020), and Klein et al. (2020). Such headland-attached sand bodies have to be carefully distinguished from the so-called banner banks (term coined by Cornish 1914), which are headland-detached sand bodies controlled by strong bi-directional tidal currents (e.g. Pingree and Griffiths 1979; Johnson et al. 1982; Signell and Harris 2000; Bastos et al. 2002, 2003; Duffy et al. 2004; Duffy 2006; Li et al. 2014).

Alongshore-transported sediments that are trapped at rocky headlands often form boundaries of the so-called 
coastal sediment compartments (e.g. Davies 1974; Bray et al. 1995; George et al. 2015; Thom et al. 2018; Goodwin et al. 2020). Several such subaqueous, headland-attached sandspits have been identified along the south coast of South Africa (Birch 1980; Flemming 1998). The present study deals with the largest of these, where alongshore sediment transport has resulted in the deposition of a huge subaqueous sand body that has prograded up to $8 \mathrm{~km}$ beyond Cape Seal, the eastern tip of the Robberg Peninsula, Plettenberg Bay, South Africa (Fig. 1). The investigation formed part of the multidisciplinary Agulhas Bank Studies programme of the former National Research Institute for Oceanology (CSIR), Stellenbosch, South Africa (cf. Schumann et al. 1982a). By integrating oceanographic, marine biological, geological, and geochemical investigations, the study aimed at gaining more comprehensive insights into this region. The main focus of the geoscience sub-programme was to investigate the inner shelf between Mossel Bay and Plettenberg Bay (Fig. 1) by means of detailed sedimentological and geophysical surveys.

The specific aim of this presentation is to provide a comprehensive overview on the topography and shape of the

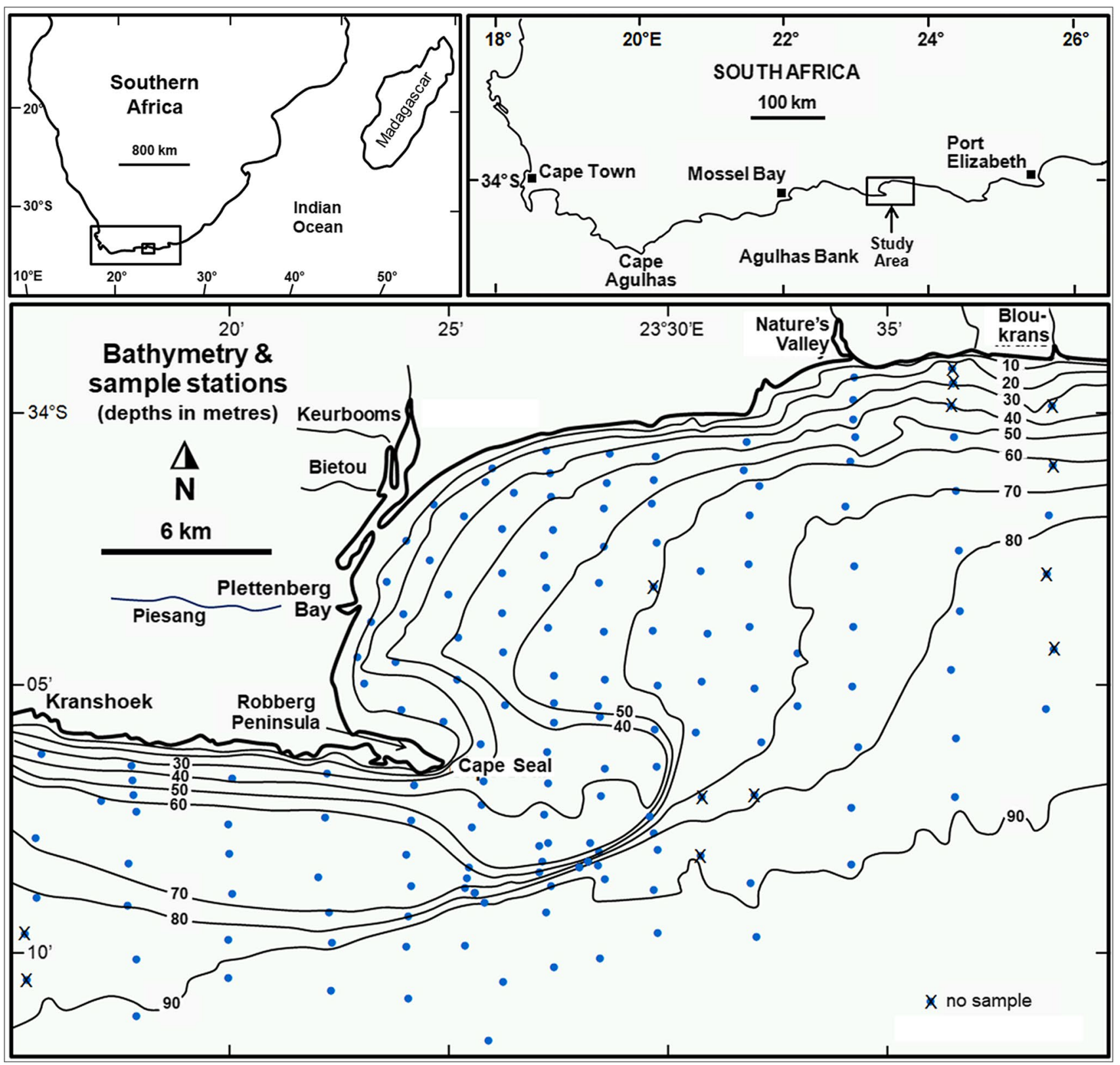

Fig. 1 Geographic location of the study area off Plettenberg Bay (Agulhas Bank, South Africa) also showing the bathymetry and sample locations 
Robberg sand-spit, its surficial sediment composition in relation to the surrounding seabed, its boundaries to other sediment compartments, and the volume of sediment stored in the spit and the adjacent sediment compartment to the north. Furthermore, because of the extraordinary size of sand bodies like the Robberg spit-bar, they are primary targets in the exploration for hydrocarbons (gas, oil).

\section{Physical setting}

\section{Geomorphology and geology}

The coastline of the study area is dominated by the headland-bay system defined by the Robberg Peninsula (Fig. 1). The peninsula is about $4 \mathrm{~km}$ long and rises up to $\sim 140 \mathrm{~m}$ above sea level. Although the official name of the embayment is Formosa Bay, it is generally referred to as Plettenberg Bay, the name of the town on its shore. The bathymetry of the area clearly outlines the massive submarine sand body (Robberg spit-bar) that extends for more than $8 \mathrm{~km}$ to the east from Cape Seal, which represents the eastern tip of the peninsula. The spit-bar reaches a maximum $\mathrm{N}-\mathrm{S}$ width of $\sim 5 \mathrm{~km}$. Within the bay, the seabed slopes rather gently at an average gradient of $1: 160\left(\sim 0.36^{\circ}\right)$, whereas south of the Robberg Peninsula, it steepens to $1: 33\left(\sim 1.74^{\circ}\right)$, and along the SE slope of the spit-bar to as much as 1:13 $\left(\sim 4.4^{\circ}\right)$. The slope gradient between the 100- and 150-m isobaths of the Agulhas Bank proper, by contrast, is only about 1:1000 $\left(\sim 0.06^{\circ}\right)$.

The onland bedrock geology is predominantly composed of sandstones and quartzites belonging to various formations of the Cape Supergroup (Ordovician) (e.g. Toerien 1976; Carr et al. 2019; cf. also Flemming and Martin 2018), which are locally overlain by conglomerates of the Enon Formation (Late Jurassic-Early Cretaceous) (e.g. Muir et al. 2017). Morphologically, the most prominent is the raised coastal platform which, at the coast, rises steeply from sea level to elevations $>100 \mathrm{~m}$. It fronts the Outeniqua Mountain range that rises to over $1000 \mathrm{~m}$ some $20 \mathrm{~km}$ inland from Nature's Valley or $35 \mathrm{~km}$ from the Robberg Peninsula (cf. Figure 1 for orientation). Local rivers are deeply incised into this coastal platform, their catchment areas being relatively small due to the proximity of the mountain watershed.

Within Plettenberg Bay, and up to $\sim 5 \mathrm{~km}$ south from Nature's Valley, the offshore basement geology consists of Ordovician rocks belonging to the Cape Supergroup. Seaward from there, the basement is composed of strongly folded and block-faulted (horst and graben structures) Upper Cretaceous rocks (Dingle et al. 1983). The transition from Mesozoic to Tertiary (Palaeogene) basement is located about $22 \mathrm{~km}$ south of the Robberg Peninsula (Dingle 1971). The surface of the Mesozoic and Tertiary sequences forming the Agulhas Bank proper has been bevelled in the course of numerous subsequent regression/transgression cycles to define the so-called Palaeo-Agulhas Plain (e.g. Cawthra et al. 2019). Whereas incised Palaeo-river valleys on the Agulhas Bank proper were backfilled by fluvial sediments in the course of the Holocene transgression (Dingle and Rogers 1972; Cawthra et al. 2020), the areas between such valleys, up to the onset of the nearshore sediment prism, are mantled by a thin veneer of relict sediment (Rogers 1971; Birch 1980).

An enigmatic geological feature is the so-called Island, a carbonate-cemented aeolianite outcrop, located just south of the central part of the Robber Peninsula (Fig. 1), and which is linked to the peninsula by a sandy tombolo. Optical luminescence dates by Carr et al. (2019) have revealed that the aeolian deposit originally formed in two phases, one from 60 to $45 \mathrm{ka} \mathrm{BP}$, the other from 35 to $30 \mathrm{ka}$ BP. The onset of eroded sands from the aeolianite being blown onto (and hence also across) the peninsula was dated at $10.2 \mathrm{ka} \mathrm{BP}$. Sea level at that time stood about $25 \mathrm{~m}$ below the present level (Cooper et al. 2018). It must therefore be anticipated that, from this time onward, sand was being blown across the peninsula to bypass the Cape Seal headland. Notable is that the aeolian sandstream crossing the peninsula is northeast aligned and thus controlled by south-westerly winds (Hellström and Lubke 1993).

\section{Climatology and oceanography}

The south coast roughly between Cape Agulhas and East London lies in the year-round rainfall corridor wedged between the winter rainfall region of the Western Cape and the summer rainfall region of the Eastern Cape and continental interior (e.g. Tyson and Preston-Whyte 2000; Chase and Meadows 2007; Truc et al. 2013). Throughout the year, the south coast is dominated by strong south-westerly winds which frequently reach velocities well in excess of 22 knots (40 km/h; cf. Hellström and Lubke 1993). Secondary winds of lower frequency blow from the SE quadrant, while easterly winds are much more infrequent.

As in the case of the wind, the wave climate of the south coast is dominated by ocean swells propagating from the south-western quadrant (e.g. Schumann et al. 1982b). The wave climate on the Agulhas Bank is characterised by periods of 5-14 s, with 10-12 s as the most frequent periods, and average significant wave heights of 2.7-3.0 m (Rossouw 1989; Joubert and van Niekerk 2013). Due to the concurring directions of the dominant winds and ocean swells, locally generated, shorter period wind waves (5-7 s) are often superimposed on the longer period swells (8-14 s), thereby considerably enhancing overall wave power.

The tidal range in Plettenberg Bay reaches almost $2 \mathrm{~m}$ at spring tide (Heydorn and Tinley 1980; cf. also Schumann et al. 1982b). As the tidal wave approaches the coast 
at almost right angles, the tidal current in the open bay is relatively weak. Wave- and wind-driven currents along the coastline up to and past Cape Seal, by contrast, are occasionally strong enough to generate small dunes in the mediumgrained sands of the spit-bar, as revealed by eastward dipping crossbeds in box cores (Flemming et al. 1983b). Also prominent are occasional upwelling events off the Robberg Peninsula which are associated with strong easterly wind events (Schumann et al. 1982a).

\section{Materials and methods}

\section{Sedimentology}

Sediment distribution patterns in the study area were reconstructed on the basis of 146 samples collected in 1982 by means of a Shipek grab sampler (Fig. 1). Sampling positions were fixed by DECCA or radar distance/angle measurements to prominent coastal features (e.g. headlands) and then transferred to a nautical chart. A map showing the numbered sampling stations and their geographic positions can be found in the Electronic Supplementary Material (ESM Table S1). The moist sediment samples were stored in sealed plastic containers.

In the laboratory, the samples were washed through a 63-micron sieve into a bowl using as little fresh water as possible. The turbid water thus generated was decanted into large containers, the procedure being repeated several times until the remaining supernatant water was clear. The containers were left standing undisturbed for several days until the suspended mud had settled out completely. The water was then siphoned off and the settled mud emptied into preweighed porcelain bowls, which were placed overnight into an oven for drying at $50{ }^{\circ} \mathrm{C}$. After drying the bowls with the mud were again weighed, the difference in weight being equated to the mud mass. The clean coarse fractions were similarly dried and weighed. The gravel fractions were then separated from the sand by dry sieving through a 2-mm sieve and both fractions thereafter weighed. The corresponding masses of all three fractions (gravel, sand, mud) were in each case added together and expressed as percentages of the total mass.

Grain-size distributions of the sand fractions were determined by settling tube (cf. Flemming and Thum 1978), whereby settling velocities were converted to equivalent settling diameters at 0.1 -phi size intervals by application of a computer algorithm based on the experimental results of Gibbs et al. (1971). Textural parameters were calculated by both percentile and moment statistics (cf. ESM Table S2). The maps showing sediment distribution patterns were generated by manual contouring.
Carbonate contents were determined on pre-weighed sand subsamples by treatment with hydrochloric acid, before being washed, dried, and weighed. The difference in weight was equated to the carbonate content, which was then expressed as a weight-percentage. Although the least accurate of several methods for carbonate determination (e.g. Carver 1971), it was considered adequate for the purpose of this study.

Identification of hydraulic populations and progressive mixing between neighbouring populations are based on the pattern originally recognised by Folk and Ward (1957) and later applied by, for example, Folk and Robles (1964) and Flemming $(1988,2015)$. Mixing trends in the present study were identified on the basis of the relation between mean diameter and sorting. Mixing between two hydraulic populations typically has the form of an inverted v-shaped progression when plotting mean diameter against sorting, whereby the parent populations are normally well-sorted. The sorting then progressively decreases up to the point of equal mixing (e.g. Folk and Ward 1957). Relative sorting (QH) is a dimensionless number value generated by normalizing the grain-size dependence of optimal sorting (also known as elementary sorting $\left.\mathrm{QD}_{\mathrm{e}}\right)$ of a sample to unity $(\mathrm{QH}=1)$. This is achieved by dividing the standard deviation (QD) of a grain-size distribution by the elementary sorting of that distribution $\left(\mathrm{QD}_{\mathrm{e}}\right)$ such that $\mathrm{QD} / \mathrm{QD}_{\mathrm{e}}=\mathrm{QH}$ (cf. Walger 1962). Flemming (2015) has subsequently shown that elementary sorting values can be as low as $\mathrm{QD}_{\mathrm{e}}=0.5$. The phi-fractions of the sand component are addressed in terms of the Wentworth (1922) classification. The compositional and textural parameters of all samples are listed in ESM Tables S1 and S2.

\section{Geophysics}

Detailed seismic boomer and pinger surveys were carried out in 1982 (boomer) and 1983 (pinger) (Fig. 2). For navigational security reasons, a safety margin of at least $1 \mathrm{~km}$ from the coast was maintained throughout the surveys. Positions were fixed at 15 -min intervals by the same procedure as outlined in the sedimentology subsection above. Data acquisition made use of sound sources fed by an EG\&G power supply at energy discharges of 100-300 J in the case of the boomer and $50 \mathrm{~J}$ in the case of the pinger. The return signals were recorded via an 8-element hydrophone array and processed by a receiver unit with bandpass filter settings of $2500-5000 \mathrm{~Hz}$ (boomer) and $4500-6500 \mathrm{~Hz}$ (pinger), before being printed on an EPC graphic recorder. The two crossing $\mathrm{N}-\mathrm{S}$ and W-E sparker profiles (Fig. 2) were extracted from an earlier regional seismic survey (Martin and Flemming 1986). In the absence of precise acoustic velocity data on the local unconsolidated sediment, a factor of 0.8 was used to convert travel time of the seismic signal within the sediment 
Fig. 2 Track chart of seismic surveys comprising pinger, boomer, and sparker sound sources. Note that the sparker profiles are presented in Figs. 9 and 10

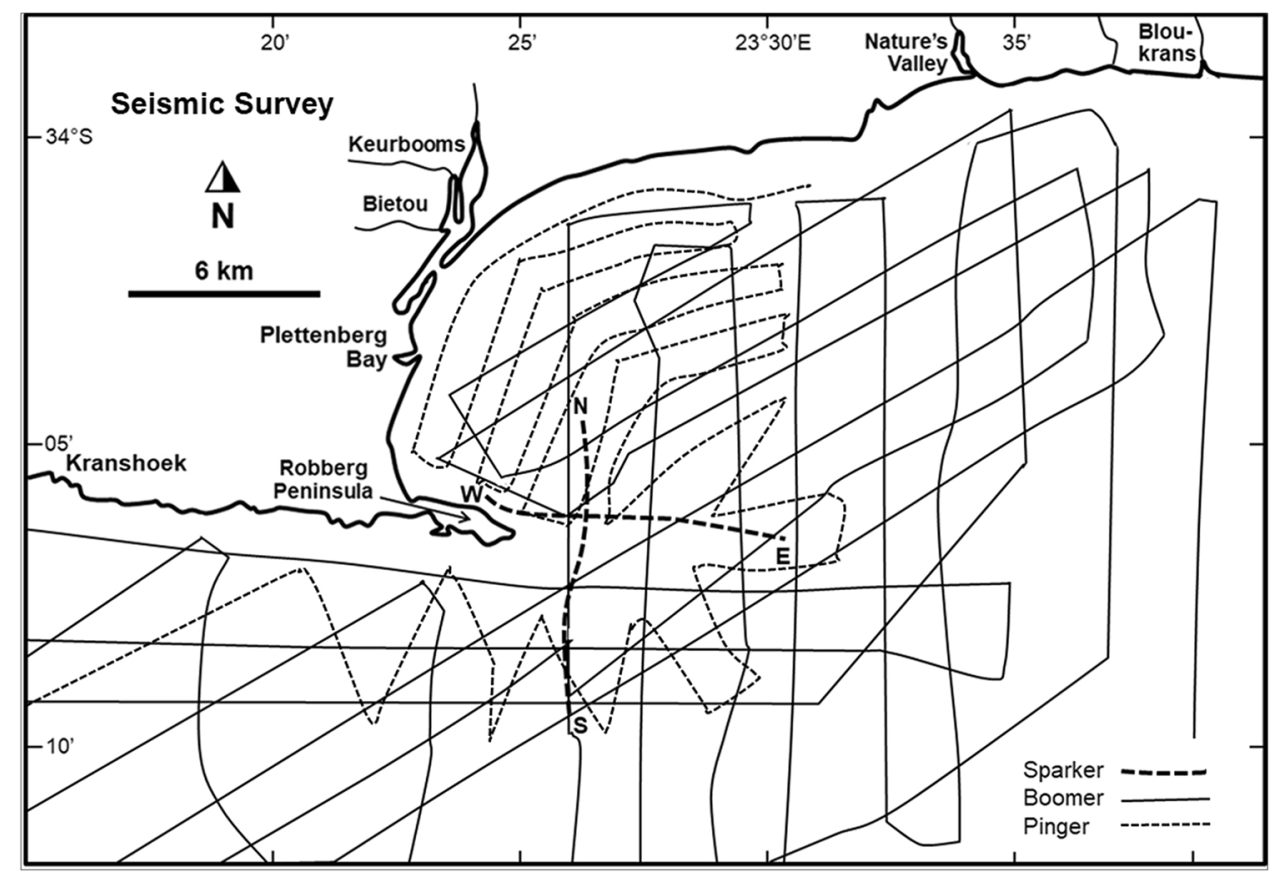

from milliseconds to sediment thickness in metres. This corresponds to a two-way travel time of $1600 \mathrm{~m} / \mathrm{s}$. The boomer typically achieved penetrations below the seabed of just over $60 \mathrm{~m}$, the pinger up to $20 \mathrm{~m}$, and the sparker $>100 \mathrm{~m}$. The sparker profiles were selected for illustration because only these reveal the internal sedimentary architecture of the Holocene deposits (Fig. 3a). In the boomer profiles, by contrast, the unconsolidated Holocene sediments are essentially transparent in spite of the seismic signal penetrating down to the rocky basement (Fig. 3b).

On the basis of the seismic surveys, a sediment thickness map was generated by manually interpolating between the closely spaced survey lines (Fig. 2). Based on this, sediment volumes (in $\mathrm{m}^{3}$ ) were determined by overlaying the map with a $500 \times 500-\mathrm{m}$ grid and multiplying the surface area of each cell $\left(250,000 \mathrm{~m}^{2}\right)$ with the sediment thickness estimated for the centre point of that cell. The total number of cells amounted to 1232, which corresponds to an area of $308 \mathrm{~km}^{2}$.

\section{Results}

\section{Sedimentology}

The relationship between mean grain size and water depth is illustrated in Fig. 4. The diagram reveals three sample groups comprised of coarse lag sediments associated with rock outcrops occurring at water depths up to $65 \mathrm{~m}$ (NB: rock platforms at water depths shallower than $30 \mathrm{~m}$ were not sampled), a medium- to fine-grained sample group spanning water depths from 10-100 m, and an overlapping fine- to very-fine-grained sample group covering water depths from 30-92 m.

The distribution patterns of individual full-phi size fractions present a remarkably clear picture (Fig. 5). Particularly noteworthy is the partitioning between the gravel + very coarse sand, coarse sand, and medium sand fractions (Fig. 5a-c), on the one hand, and the fine sand, very fine sand, and mud fractions (Fig. 5d-f), on the other. This suggests that the sediments are overall dominated by coarsegrained parent populations on the one side, and fine-grained ones on the other, individual populations overlapping to various degrees in particular areas. Also notable is that the water depth of the 'mud belt' seaward of the spit, which is wrapped around the base of the sand-spit and is composed of muddy fine sand (Fig. 5f), occupies a depth range of about 60-90 m, whereas the separate mud depocentre within the bay has a depth range of about $35-65 \mathrm{~m}$. This is a clear reflection of the progressively decreasing wave energy at the seabed towards the rear of the spit. The spatial separation of the depocentres also suggests that the muds have different sources. Thus, the mud forming the belt seaward of the spit must obviously have its source to the west of the study area, whereas the mud within the bay is most likely supplied by the Piesang/Bietou/Keurbooms river system which discharges into the bay (cf. Figure 1). Stratigraphically, the spit-bar thus represents an upward coarsening sediment sequence, ranging from muddy fine sand at the bottom, followed by fine sand that grades into medium sand towards the top. 
Fig. 3 Comparison between a sparker (a) and a boomer (b) seismic profile showing similar slope sections of the Robberg spit-bar. Note the definition of the internal master bedding in the former and the transparency of the latter profile. The two profiles had similar orientations but were recorded on different graphic printers; the horizontal and vertical scales are almost identical; noise in the water column has been manually removed; the scales in image a also apply to image $\mathbf{b}$
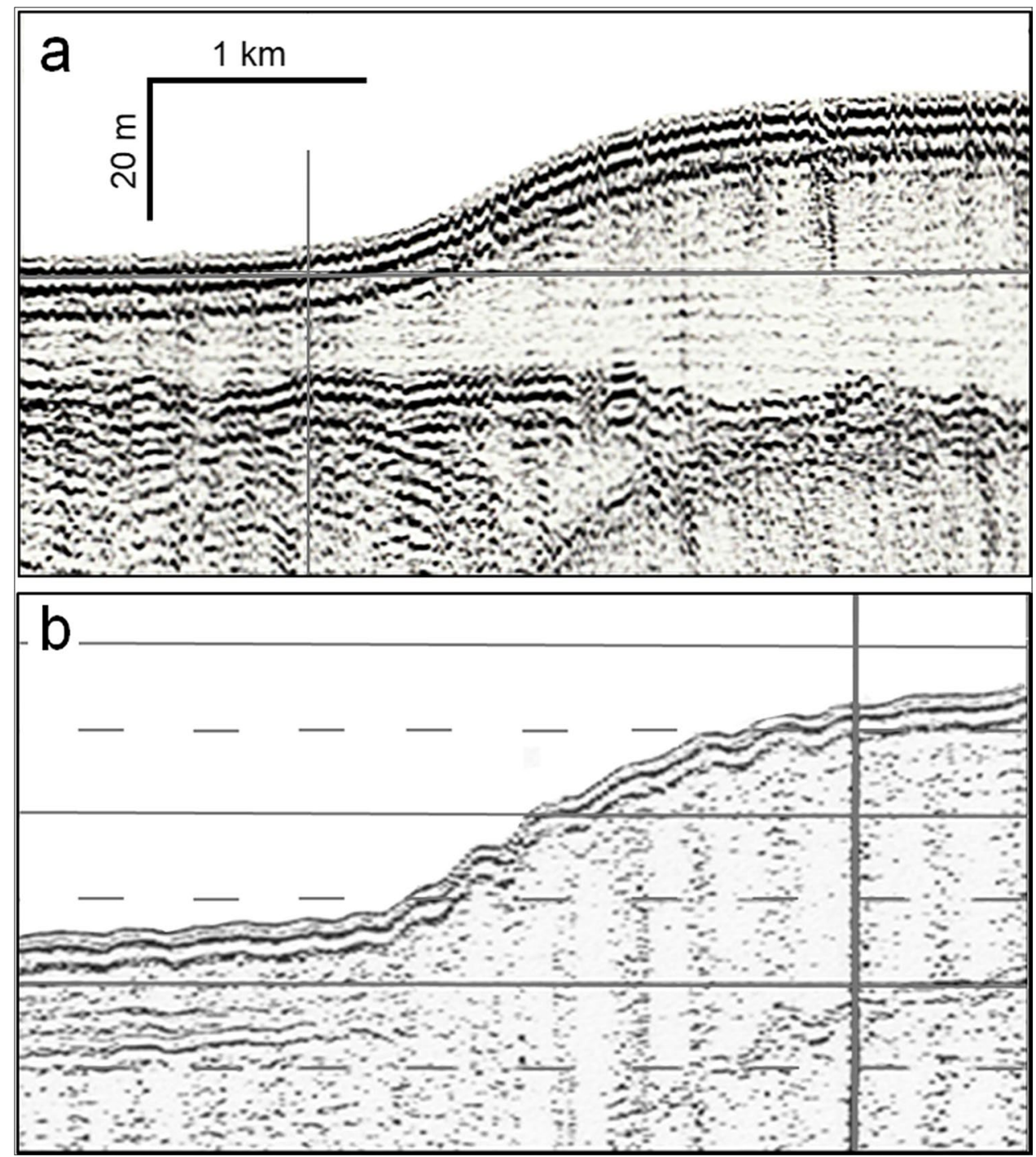

Based on the bathymetry and the distribution maps of the various sedimentary facies, the study area can be tentatively divided into four sedimentary compartments (A, B, C, D) that are separated by quite distinct boundaries (Fig. 6). Thus, compartment $\mathrm{A}$ is composed of sediment transported into the study area from the west, the main sources probably being the coastal aeolianites in the Wilderness embayment (Birch et al. 1978; Flemming et al. 1983a; Cawthra et al. 2014), nearshore bioclastic sediment production, and a fluvial input from small rivers. Compartment B is composed of sediment supplied by the Piesang/Bietou/Keurbooms river system. Compartment C, in turn, defines the Tsitsikamma coastal shelf which receives its sediment essentially from the adjacent hinterland (cf. Flemming and Martin 2018). The seabed of compartment $\mathrm{D}$, which borders on compartments $\mathrm{A}$ and $\mathrm{C}$ along their offshore boundaries, is composed of relict (i.e. palimpsest) sediments related to the drowned 'Palaeo-Agulhas Plain' as defined by Cawthra et al. (2019). The nearshore Holocene sediment prisms of compartments $\mathrm{A}, \mathrm{B}$, and $\mathrm{C}$ are superimposed on this former Pleistocene land surface.

The distribution of carbonate contents $\left(\mathrm{CaCO}_{3}\right)$, mean diameters, relative sorting, and skewness are illustrated in Fig. 7a-d, respectively. Of these parameters, the mean diameter map (Fig. 7b) reflects the average local sediment composition and is inherently compatible with the compartmentalised subdivision. The skewness map (Fig. 7d), by contrast, highlights the coarser-grained fractions as being predominantly negatively skewed and the finer-grained fractions as being predominantly positively skewed, irrespective of where they occur. Sorting (Fig. 7c), in turn, reflects the degree of mixing/unmixing between coarser-grained and finer-grained populations, progressively poorer sorting generally indicating increasing mixing. The least correlation 


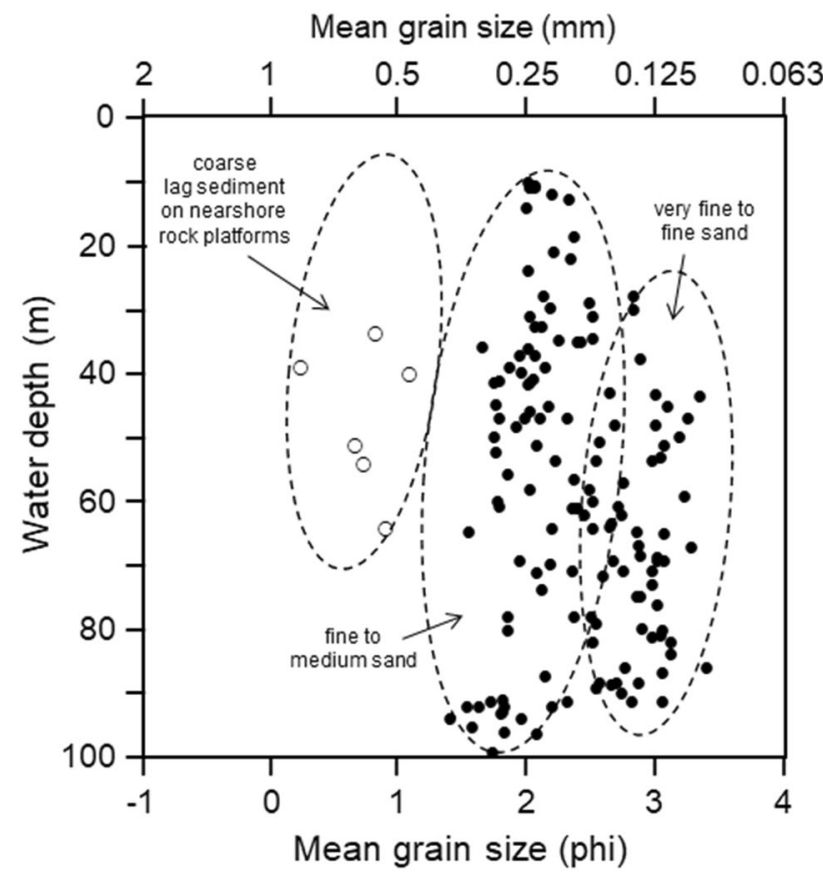

Fig. 4 Distribution of mean grain sizes with respect to water depth. Three groups can be distinguished: coarse lag deposits on nearshore rocky abrasion platforms, fine-to-medium sands of the open shelf, and fine-to-very-fine sands in the bay proper

with any of the sediment facies and textural parameters is observed in the spatial distribution of $\mathrm{CaCO}_{3}$ (Fig. 7a), especially in the central part of the study area. The only exception is the north-eastern nearshore zone which is dominated by lag deposits on rock platforms exposed on the seabed which comprise variable mixtures of siliciclastic and bioclastic coarse-grained sediments.

Mixing processes between hydraulic populations are best identified in scatter plots between individual textural parameters, particularly mean grain size vs sorting. When plotting the corresponding parameters of all samples together, the diagram presents a rather complex picture (Fig. 8a). This suggests that potential mixing progressions in different areas have been superimposed on each other, as a result of which individual trends are obscured. To disentangle these, the data were plotted separately for each sediment compartment (Fig. 8b-f). Of these, the mixing trends of subcompartments A-west, A-north, and A-east were found to be so similar that the data were pooled in a single diagram (Fig. 8b). These are composed of fine-very fine sand, with a well-defined medium-fine sand parent population. Of interest here is that the very-fine-sand population only occurs in mixed form, i.e. it lacks its own spatially defined depocentre within compartment A. This can be explained by the fact that the main source of the sediment in compartment $\mathrm{A}$ is in all likelihood the aeolianites in the Wilderness embayment, which are predominantly composed of fine-medium sand. The trend in compartment A-centre, by contrast, differs markedly from the other sub-compartments (Fig. 8c). It is dominated by medium sand (up to $75 \%$ ) which occupies the wave-swept top of the spit-bar (cf. Figure 5c), and where it is mixed with some fine sand towards the northern edge of the sub-compartment.

The clearest mixing progression, involving a fine-sand and a very-fine-sand population, is seen in the plot of compartment B (Fig. 8d). This compartment is wedged between compartments $\mathrm{A}$ and $\mathrm{C}$, the latter having previously been identified as a self-contained compartment (Flemming and Martin 2018). The fine-sand population occupies the shallow-water region off the Bietou/Keurbooms river mouth, whereas the very-fine-sand population dominates the deeper offshore region of that compartment, the two overlapping in the area in between to present the image of a complete mixing progression. The available data provides no evidence for substantial mixing across the boundary between compartments A and B. Although one would expect such boundary mixing to occur, it seems to be spatially so restricted that, in order to be recognised, it would require very closely spaced sampling across the boundary.

The boundary between compartments B and C mostly borders on rock platforms which prevent (or strongly inhibit) mixing in that direction. This is highlighted by the mixing pattern observed in compartment C (Fig. 8e) which clearly bears no resemblance to that in compartment $\mathrm{B}$. The same applies to compartment D (Fig. 8f) which, as pointed out above, is dominated by medium- to coarse-grained relict sediments (Rogers 1971; Birch 1980) and a very-fine-sand drape near its boundary to compartments A and C. This suggests that much of the very-fine-sand population, which was found to be in short supply in compartment $\mathrm{A}$, has been carried eastward across the compartment boundary into compartment $\mathrm{D}$, an interpretation that is supported by the distribution map of very fine sand (Fig. 5e).

\section{Geophysics}

Although the seismic energy of the boomer was sufficient to penetrate the greatest thickness of the spit-bar $(\sim 65 \mathrm{~m})$ down to the Cretaceous bedrock, the sediment body remained essentially transparent. In order to visualise the depositional style, two sparker profiles were extracted from an earlier survey (Martin and Flemming 1986). The two profiles cross each other more or less at right angles (cf. Figure 2), one being oriented N-S (Fig. 9), the other W-E (Fig. 10).

A particular feature of the sparker records is that the internal master bedding reveals a marked change in depositional style more or less in the middle of the sand body. It can be recognised by a distinct unconformity that divides the deposit into two major units. The lower unit is characterised by more or less conformable, low-angle clinoforms, whereas 

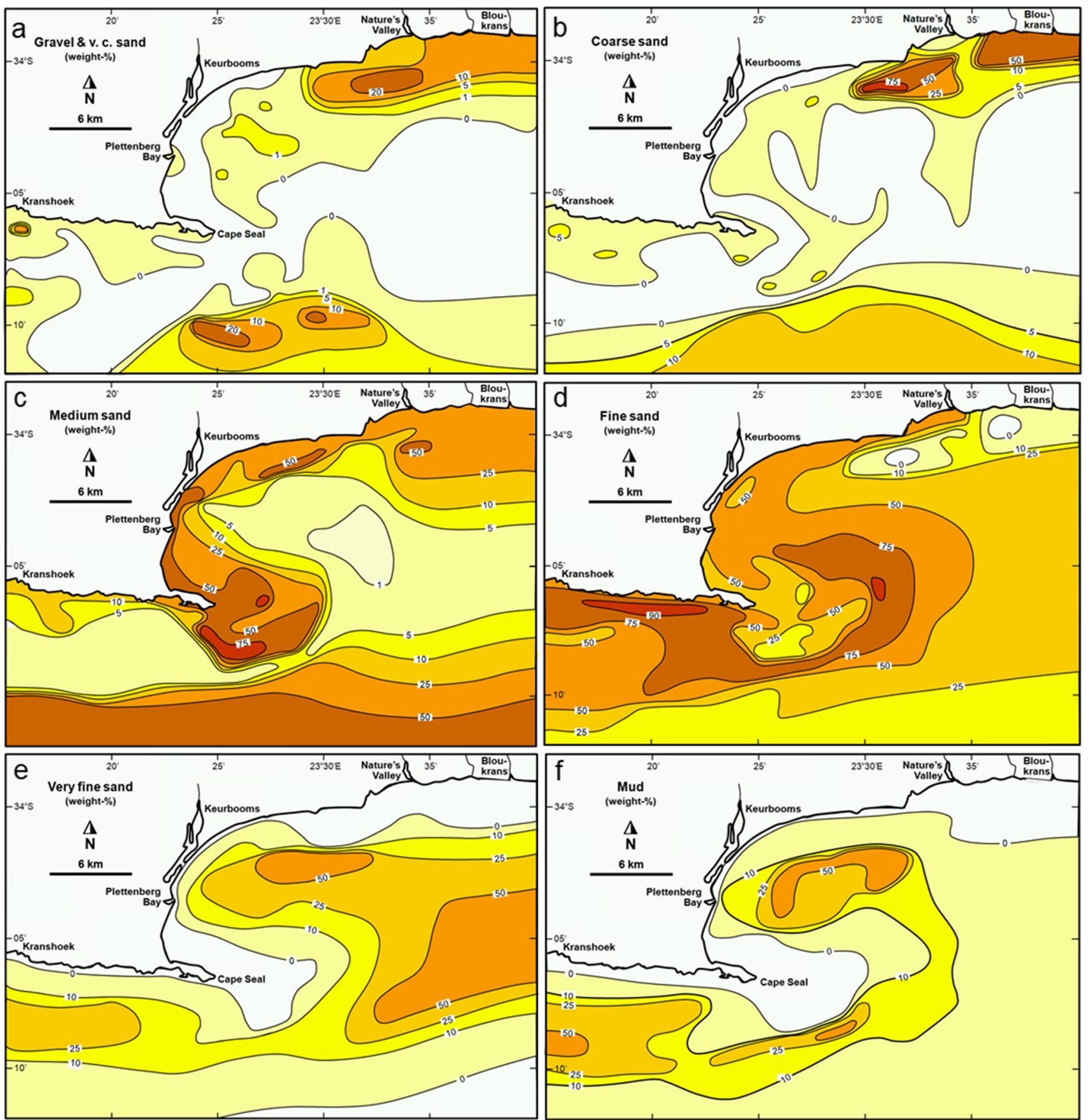

Fig. 5 Distribution of individual size fractions at phi-intervals (a-e) following the modified Wentworth (1922) classification. a Gravel and very coarse sand ( $>0$ phi). b Coarse sand (0-1 phi). c Medium sand (1-2 phi). d Fine sand (2-3 phi). e Very fine sand ( $3-4$ phi). f Mud ( $<4$ phi)

the upper unit appears more chaotic, displaying clinoforms which, in the $\mathrm{N}-\mathrm{S}$ profile, dip more steeply towards the edges of the spit-bar, both northwards and southwards (Fig. 9), but more uniformly eastwards in the longitudinal profile (Fig. 10). As already indicated by the bathymetry (cf. Figure 1), the spit-bar spreads out in all directions once it clears the tip of the Robberg Peninsula (Cape Seal). In both profiles, the clinoforms steepen towards the outer edges, in particular on the southern and eastern sides of the spit-bar where the slope gradient locally attains $4.4^{\circ}$.

The longitudinal sparker profile commences to the north of the Robberg Peninsula (cf. Figure 2), where it shows eastward dipping clinoforms downlapping in fan-like fashion onto successive beds of the upper unit (Fig. 10). The downlapping clinoforms evidently belong to a fan produced by the deposition of sediment supplied 
Fig. 6 Sediment compartments (A-D) defined on the basis of bathymetry, sediment distribution patterns, and sediment thicknesses

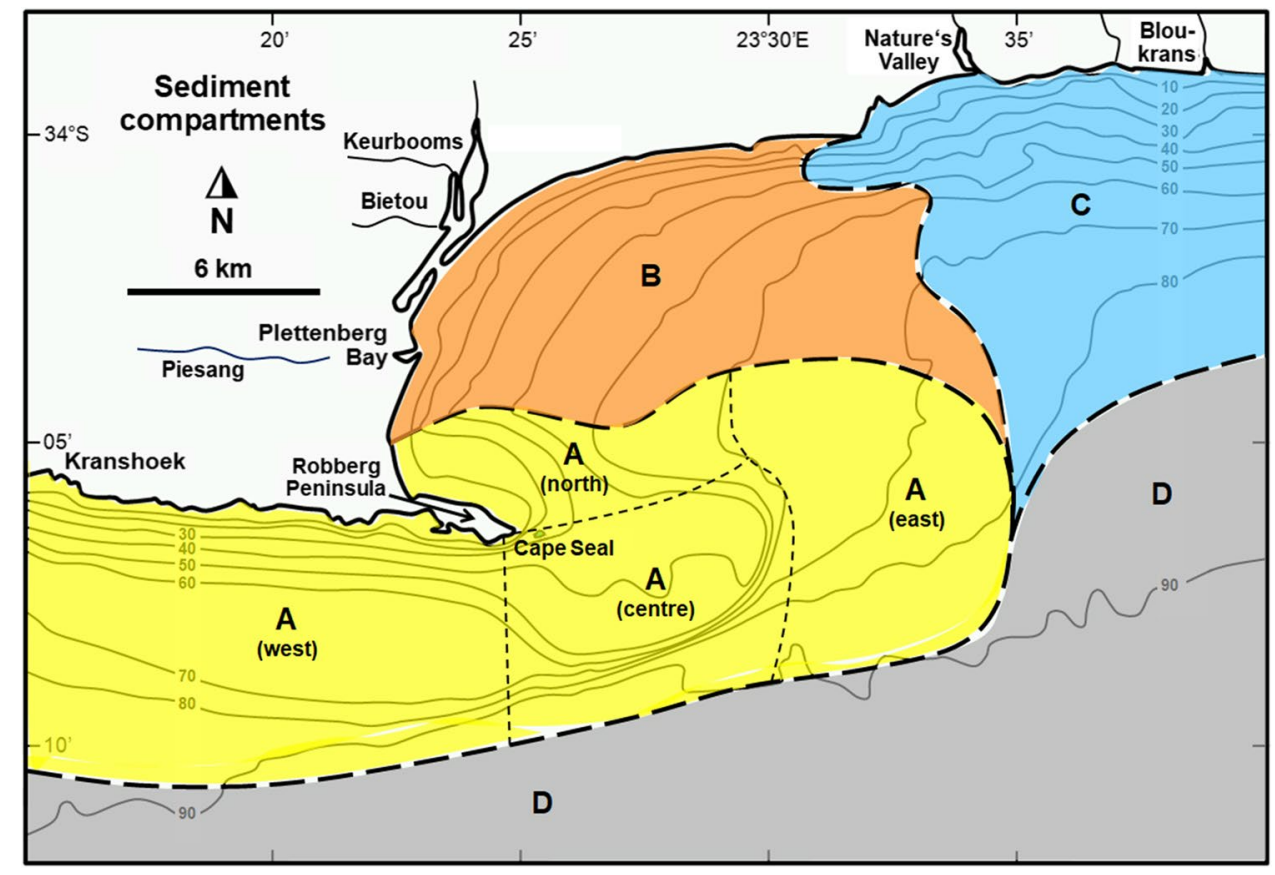

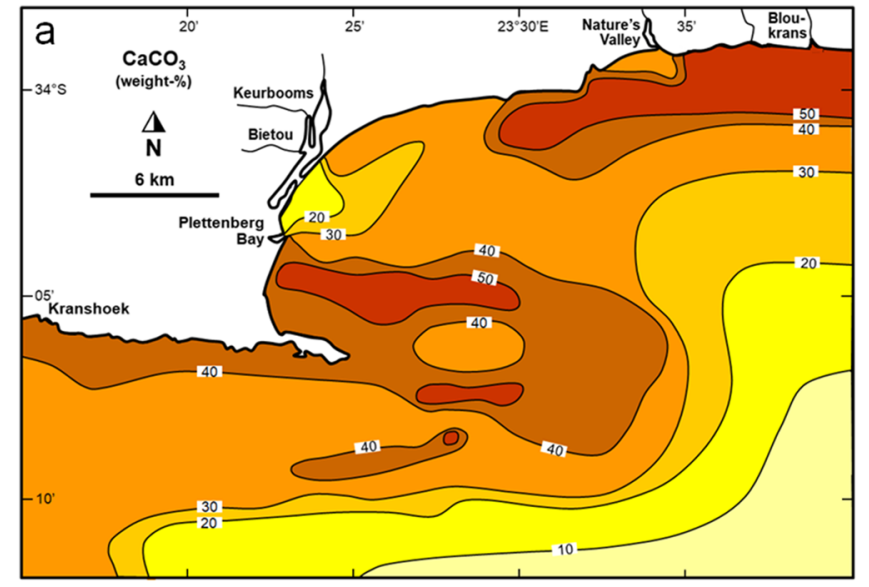
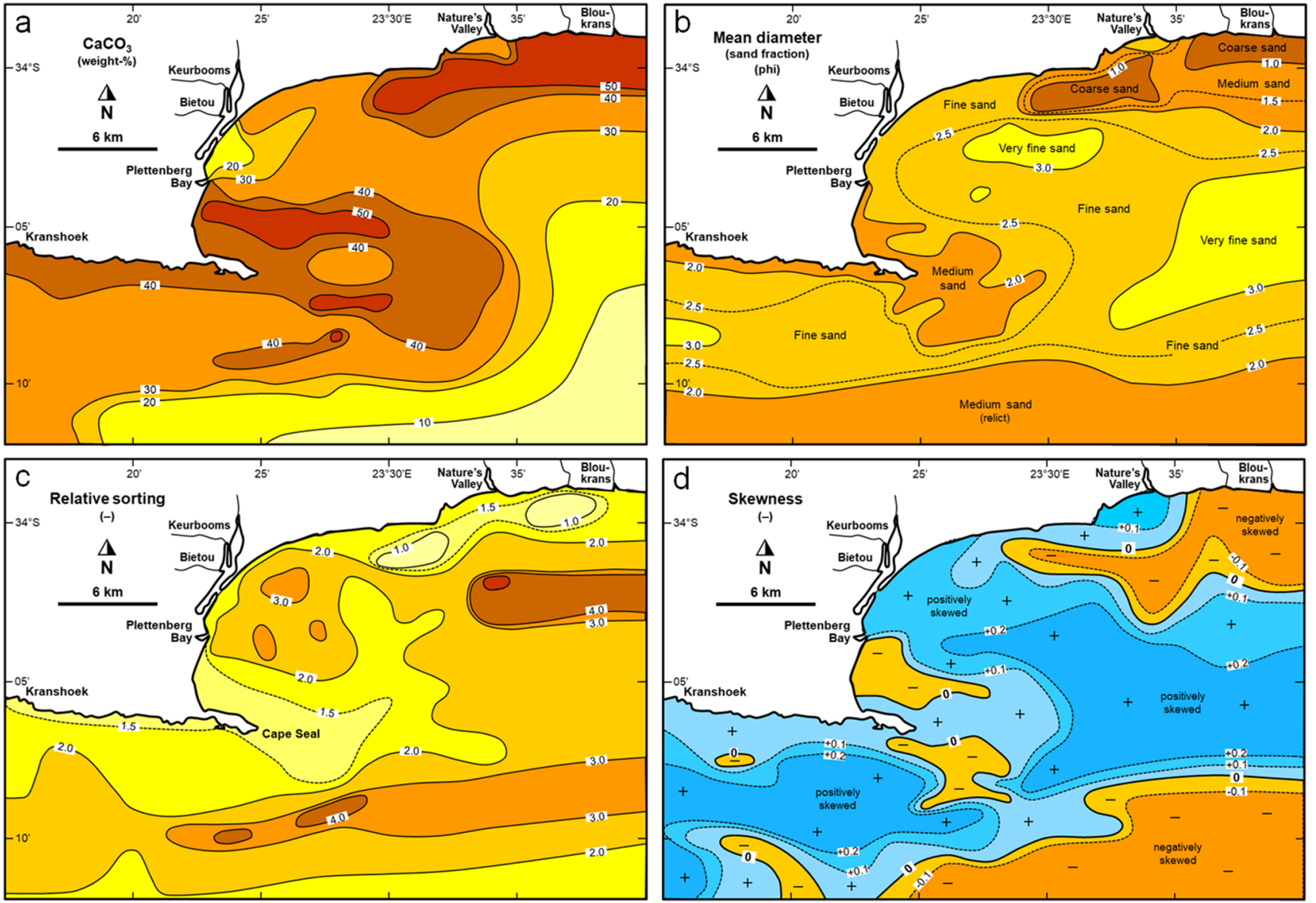

Fig. 7 Distribution of carbonate contents and textural parameters of the sand fractions (based on percentile statistics after Folk and Ward 1957). a Carbonate content (wt\%). b Mean diameters (phi). c Relative sorting (dimensionless). d Skewness (dimensionless) 

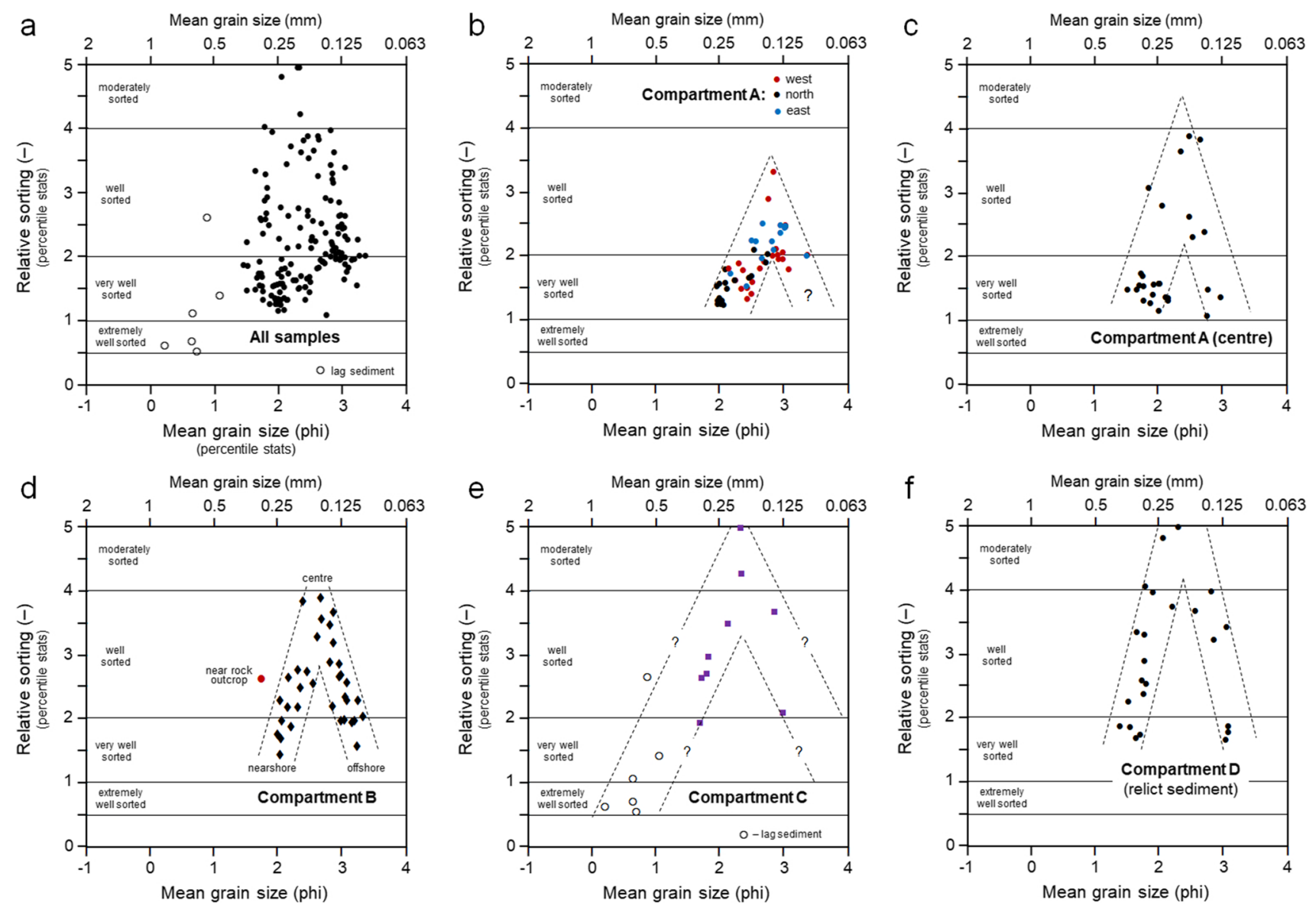

Fig. 8 Scatter diagrams of mean diameters vs relative sorting for the individual sediment compartments. a All samples of all four compartments. b Compartment A-west, A-north, and A-east. c Compartment

A-centre. d Compartment B. e Compartment C. f Compartment D. Note the distinct mixing trends, although the fine endmember is missing in $\mathbf{b}$ and $\mathbf{e}$
Fig. 9 North-South seismic cross-section (sparker) across the Robberg submarine spit-bar (a original profile; $\mathbf{a}^{*}$ interpreted profile). For location of the profile, see Fig. 2

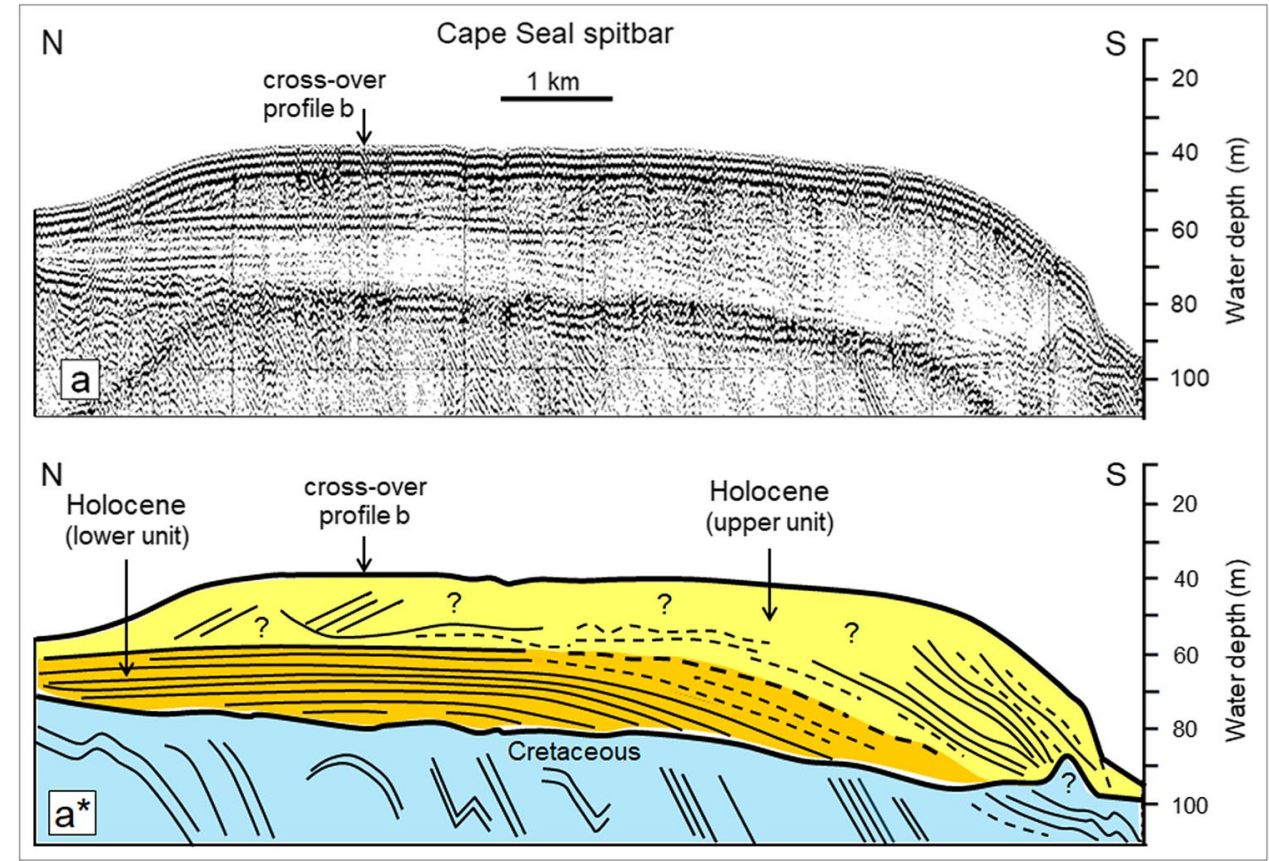


Fig. 10 West-East seismic cross-section (sparker) across the Robberg submarine spit-bar (b original profile; $\mathbf{b}^{*}$ interpreted profile). For location of the profile, see Fig. 2

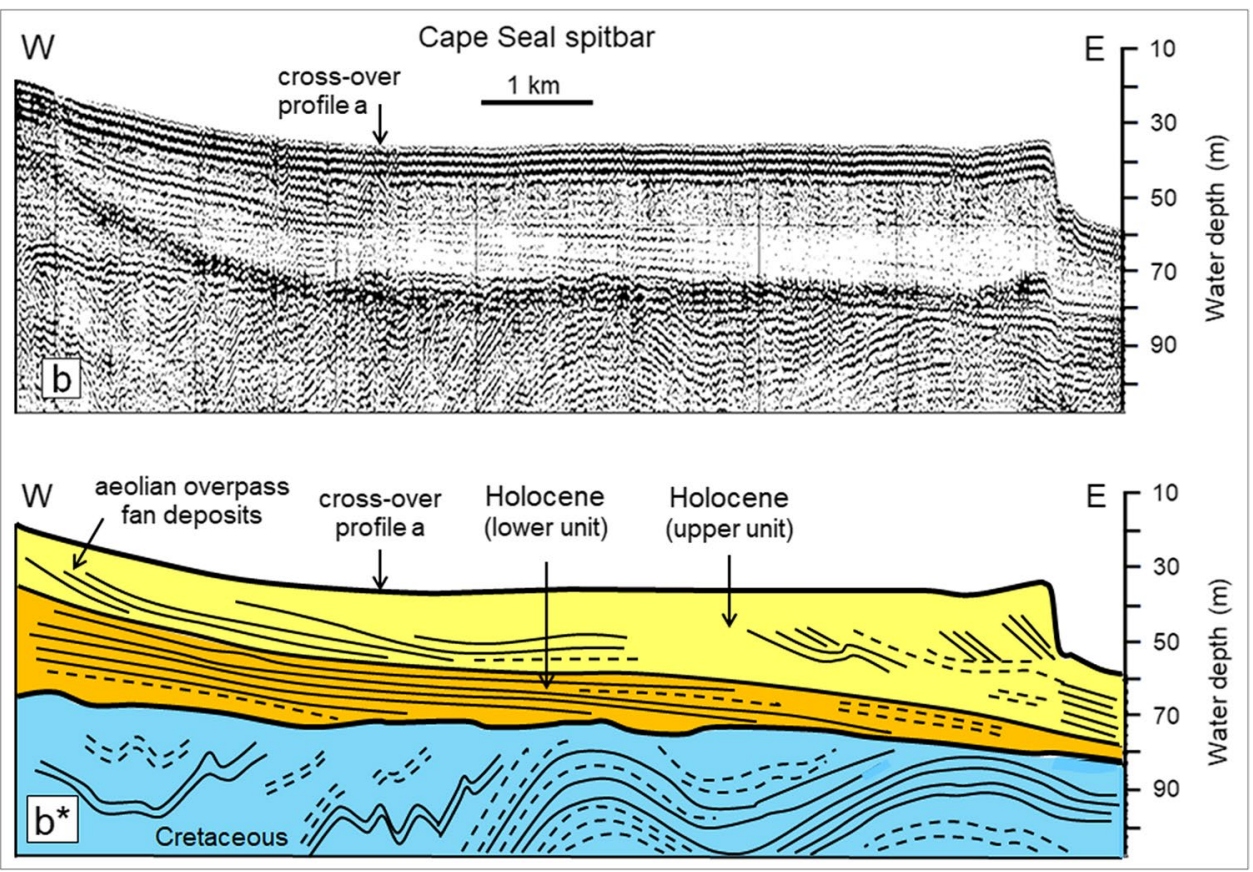

by aeolian overpass from the seaward side of the Robberg Peninsula. The boundary of this fan is morphologically well-defined by the change in isobath orientation within the bay from north-south to west-east (Fig. 11). The fan is apparently in part perched upon upper shoreface sediments of the bay.
The sediment thickness map in Fig. 12 was used to estimate the sediment volumes stored in compartments $\mathrm{A}$ and B. As pointed out in the "Materials and methods" section, total sediment volumes were determined by adding together the volumes of the 725 cells in the case of compartment A (Table 1), and those of the 520 cells in the case of compartment B (Table 2), each cell measuring $500 \times 500 \mathrm{~m}$, the
Fig. 11 Perched sand deposit on the northern side of the Robberg Peninsula produced by aeolian overpass from the tombolo beach on the southern side of the peninsula

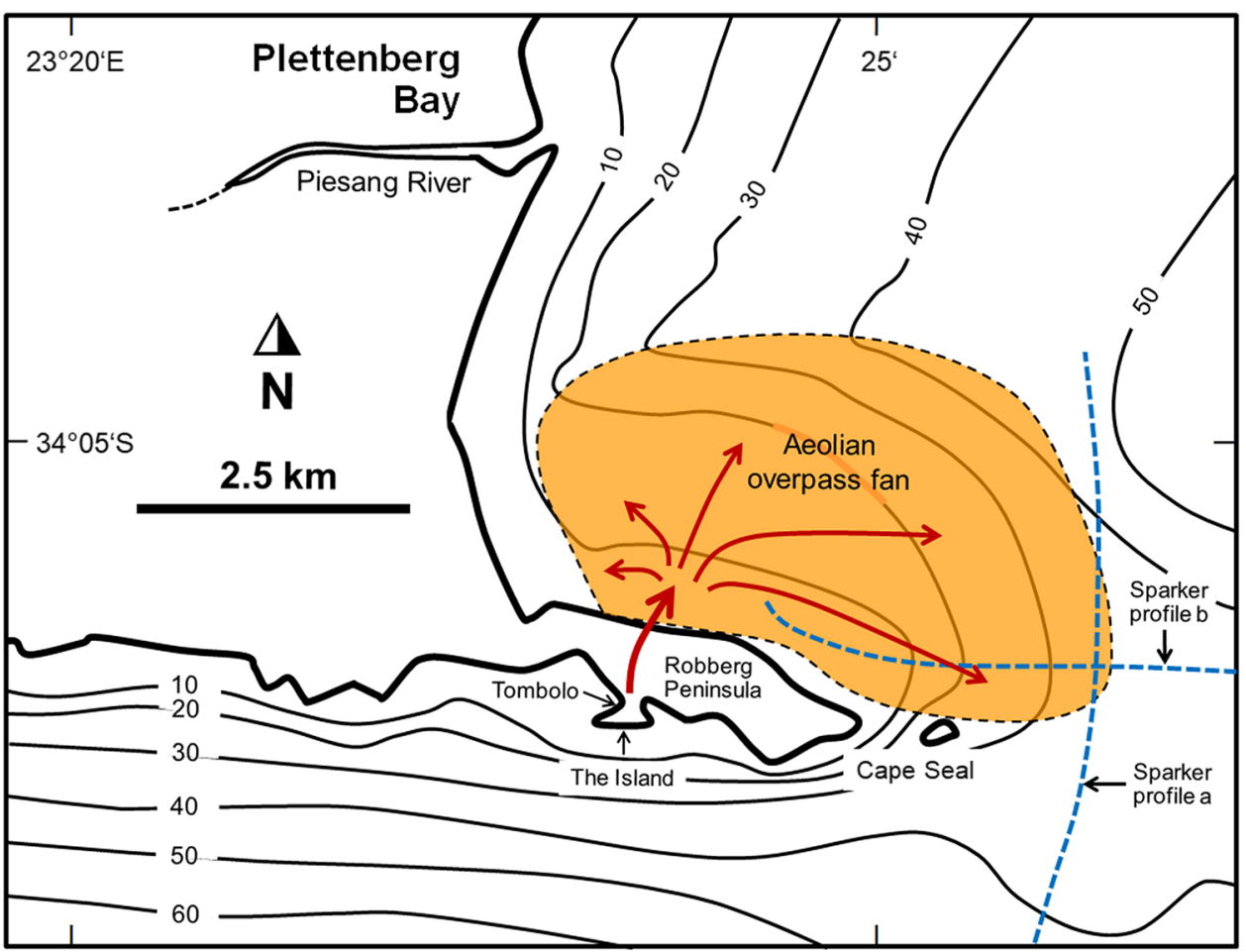


Fig. 12 Holocene sediment thicknesses in the study area. Note the large thickness $(>60 \mathrm{~m})$ of the submarine spit-bar

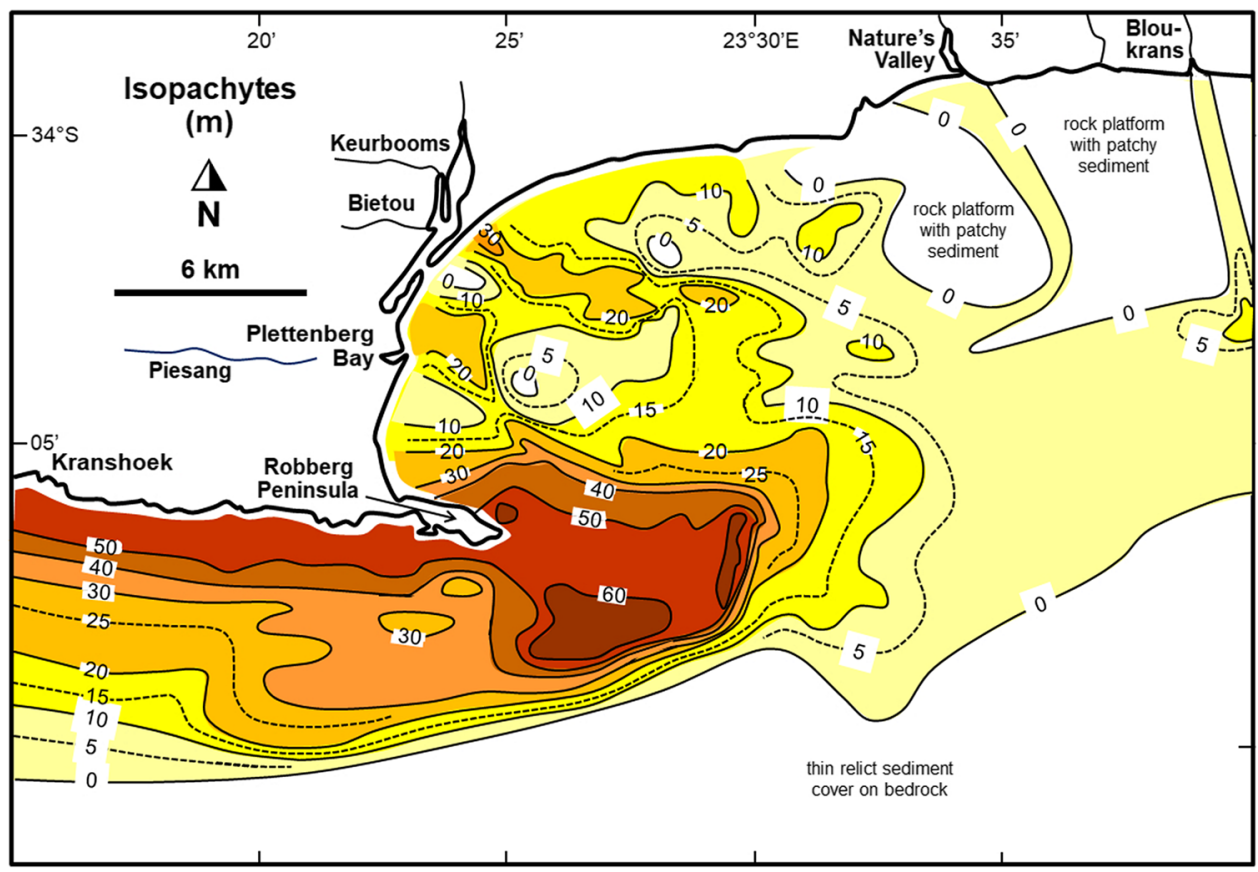

surface area thus amounting to $250,000 \mathrm{~m}^{2}$. In this way, the total sediment volume for compartment A was estimated at $5.815 \mathrm{~km}^{3}$, and that for compartment B at $0.127 \mathrm{~km}^{3}$. The distribution pattern of sediment thicknesses by and large lends further support to the correct choice of the boundaries for the proposed sediment compartments. Although the northern boundary is less clearly defined by sediment thicknesses, it must be remembered that the aeolian overpass fan pinches out in all directions. The bathymetry, on the other hand, is very clear in this respect.

Table 1 Calculated sediment volumes per 10-m thickness interval in sediment compartment $\mathrm{A}$ which accumulated in ca. 12,000 years by alongshore transport from the west

\begin{tabular}{llll}
\hline $\begin{array}{l}\text { Thickness interval } \\
(\mathrm{m})\end{array}$ & $\begin{array}{l}\text { Average } \\
\text { thickness } \\
(\mathrm{m})\end{array}$ & $\begin{array}{l}\text { Number } \\
\text { of cells* }\end{array}$ & Sediment volume $\left(\mathrm{m}^{3}\right)$ \\
\hline$>60$ & 62 & 32 & $496,000,000$ \\
$50-60$ & 55 & 138 & $1,897,500,000$ \\
$40-50$ & 45 & 88 & $990,000,000$ \\
$30-40$ & 35 & 139 & $1,216,250,000$ \\
$20-30$ & 25 & 94 & $587,500,000$ \\
$10-20$ & 15 & 134 & $502,500,000$ \\
$0-10$ & 5 & 100 & $125,000,000$ \\
Total $\left(\mathrm{m}^{3}\right)$ & & 725 & $5,814,750,000$ \\
Total $\left(\mathrm{km}^{3}\right)$ & & & $\sim 5.815$ \\
\hline
\end{tabular}

$* 1$ cell $=500 \times 500 \mathrm{~m}=250,000 \mathrm{~m}^{2}$

\section{Discussion}

\section{Sedimentological aspects}

Previous studies of headland-attached sand bodies essentially focussed on their morphology, thickness, and associated bypass/overpass processes (cf. Klein et al. 2020, for an overview). However, only a few of these also considered adjacent sediment compartments or were accompanied by such detailed sediment data as presented in the present study. Thus, Cascalho et al. 2014) and McCarroll et al. (2018) observed grain-size sorting in the course of aeolian overpass processes, where the blowout material from the beaches became finer with distance and elevation above sea level. This was partly also associated with particle density sorting (Cascalho et al. 2016; Ribeiro 2017). In the present case, overpassing was (is)

Table 2 Calculated sediment volumes per 10-m thickness interval in sediment compartment B which accumulated in ca. 12,000 years on the nearshore shelf outside the estuaries

\begin{tabular}{lllc}
\hline $\begin{array}{l}\text { Thickness interval } \\
(\mathrm{m})\end{array}$ & $\begin{array}{l}\text { Average } \\
\text { thickness } \\
(\mathrm{m})\end{array}$ & $\begin{array}{l}\text { Number } \\
\text { of cells* }\end{array}$ & Sediment volume $\left(\mathrm{m}^{3}\right)$ \\
\hline $30-40$ & 35 & 4 & $1,000,000$ \\
$20-30$ & 25 & 52 & $13,000,000$ \\
$10-20$ & 15 & 188 & $47,000,000$ \\
$0-10$ & 5 & 263 & $65,750,000$ \\
Total $\left(\mathrm{m}^{3}\right)$ & & 507 & $126,750,000$ \\
Total on shelf & & & $\sim 0.127 \mathrm{~km}^{3}$ \\
\hline
\end{tabular}

$* 1$ cell $=500 \times 500 \mathrm{~m}=250,000 \mathrm{~m}^{2}$ 
not associated with additional grain-size sorting as the aeolian source material was already optimally sorted.

While most previous studies also identified sediment bypassing processes, the data presented in this study does not favour such a mechanism. First of all, the fairly flat top of the spit-bar lies at a depth of around $35 \mathrm{~m}$ below sea level and is composed of well-sorted medium sand with mean grain sizes in the range of $1.5-2.0 \mathrm{phi}(0.35-0.25 \mathrm{~mm})$. The regional wave climate is evidently responsible for limiting the vertical accretion of the bar, which implies that grain sizes finer than those forming the top of the bar are transported across the bar to be deposited in deeper water on its down-current slopes. This is in agreement with the sediment maps of Fig. 5c, d and Fig. 7b. Hydrodynamic considerations support this interpretation. The wave climate on the Agulhas Bank is dominated by waves of $10-12$-s periods and significant heights of $\sim 2.5 \mathrm{~m}$, which reach occurrence frequencies of around $30 \%$ and $25 \%$, respectively (Rossouw 1989; MacHutchon 2006).

As the waves generally approach the coast from the SW, i.e. oblique to the W-E-aligned coastline of the study area, this generates an eastward directed alongshore current. The wave-induced maximum orbital velocity as a function of the dominant wave period and wave height at a depth of $35 \mathrm{~m}$ is $\sim 33 \mathrm{~cm} / \mathrm{s}$. The wave-induced threshold velocity for 12 -s waves at that water depth and a grain size of $0.3 \mathrm{~mm}$ ( $\sim 1.74$ phi) is $\sim 23 \mathrm{~cm} / \mathrm{s}$ (cf. Clifton 1976; Flemming 2005, and ESM Table 3). This means that the near-bed orbital velocity at the bar top exceeds the threshold velocity by at least $10 \mathrm{~cm} / \mathrm{s}$ which, augmented by an alongshore current of variable speed, is sufficient to generate wave- and currentgenerated ripples, and occasionally even small dunes, in the medium-grained sand (Flemming et al. 1983b). At the same time, finer-grained sediment is lifted into intermittent suspension by the passing waves to be progressively displaced eastwards by the longshore current. Upon reaching the edges of the bar, the current velocity reduces sharply due to flow expansion over deeper water and thereby causes the suspended finer-grained sands and mud aggregates to be deposited in deeper water along the lower slope. In this process, some of the very fine sand and mud may be transported across the eastern boundary of compartment A, mainly into compartment D.

Furthermore, due to the water depth at the bar top (35 m), it is inconceivable that sediment is transported around Cape Seal and upward to the beach of the bay. On the contrary, even the aeolian overpass fan, the top of which reaches water depths just under $10 \mathrm{~m}$ (Fig. 11), is morphologically so welldefined that, if at all, only very minor amounts of sand will be transported to the beach from that depth to continue its journey northwards along the coast. To test this, the equation of Hallermeier (1978, 1981; cf. also Hamon-Kerivel et al. 2020) for the calculation of closure depth was applied, i.e. the depth for offshore/onshore transport of sediment on the most active part of the shoreface:

$d_{\mathrm{cl}}=2.298 H_{\mathrm{s}}-68.5\left(H_{\mathrm{s}}^{2} / g T_{\mathrm{s}}^{2}\right)$

where $d_{\mathrm{cl}}$ is the closure depth, $H$ is the significant wave height, $T$ the significant wave period, and $g$ the gravitational acceleration. Using the most frequent offshore wave periods for the Plettenberg Bay region (10, 11, and $12 \mathrm{~s}$ ), and using an unrealistic wave height of $5 \mathrm{~m}$ in each case, the corresponding closure depths would be $9.65,10.2$, and $10.5 \mathrm{~m}$. For a more realistic significant storm wave height of $3 \mathrm{~m}$ in the rear of the peninsula, the corresponding closure depths would be $6.2,6.4$, and $6.5 \mathrm{~m}$. As the amount of sediment mobilised in this zone decreases exponentially with depth, any material exchange beyond the closure depth becomes insignificant. These results are in good agreement with other recent studies (e.g. Hamon-Kerivel et al. 2020; McCarroll et al. 2021). On account of these considerations, it is discounted that a tangible amount of sediment can bypass the Robberg Peninsula in the form of alongshore transport on the upper shoreface.

\section{Geophysical aspects}

\section{Robberg spit-bar}

In the seismic cross-sections of Figs. 9 and 10, a marked internal reflector at a depth of about $60 \mathrm{~m}$ below the present sea level reveals a distinct change in the depositional style from gradual vertical accretion and progradation (low-gradient clinoforms) to accelerated progradation (more steeply dipping clinoforms). Important to note here is that the two units are not separated by an erosion surface that would be indicative of a time gap. Instead, deposition continued uninterrupted, but with a change in depositional style, which is interpreted as reflecting an increase in sediment supply from the western sources, especially the aeolianites off the Wilderness coast. This would have occurred when sea level stood about $40 \mathrm{~m}$ below the present. According to the sea-level curve of Cooper et al. (2018), this would correspond to the end phase of the so-called sea-level slowstand of Pretorius et al. (2016) at about $10.6 \mathrm{ka} \mathrm{BP}$, when sea level rose by $\sim 1 \mathrm{~m} / 200$ years (cf. also de Lecea et al. 2017; Cooper et al. 2018). Up to that depth only, a small part of the coastal aeolianites occupying the Wilderness embayment was exposed to wave erosion (Martin and Flemming 1986). Shortly after this time marker, the sea-level rise accelerated more than fivefold to $\sim 5.7 \mathrm{~m} / 200$ years until $\sim 10 \mathrm{ka}$ $\mathrm{BP}$, in the course rapidly inundating a much larger part of the coastal aeolianites. The inferred increase in erosion and longshore sediment transport resulted in more rapid progradation and accretion of the spit-bar, which would explain 
the change in sedimentation style observed in the seismic profiles. According to Carr et al. (2019), aeolian sand overpassing the Robberg Peninsula commenced about $10.2 \mathrm{ka}$ $\mathrm{BP}$ and up to the present resulted in the accretion of $\sim 0.22$ $\mathrm{km}^{3}$ of sand in the perched fan in its rear. The overpass fan is considered to form part of sediment compartment A because its source is also located west of Cape Seal. Together with the spit-bar proper, the overall volume of compartment A amounts to almost $6 \mathrm{~km}^{3}$ of sediment.

\section{Shelf facies models and hydrocarbon exploration}

A sedimentary facies has been defined as a body of sediments or sedimentary rock with specific petrophysical properties (geometric shape, sedimentary units, composition and texture of sediments, fossils) which may be distinguished from other sedimentary units based on these properties (e.g. Reading 1978; 1981; Swift and Thorne 1991; Selley 1995; Miall 1999; Swift et al. 1991). A facies is considered to be the response to processes in a specific environment, whether alluvial/fluvial, coastal, shelf, or deep water. Over and above academic interest, mapping the distribution of facies within sedimentary sequences is important in oil and gas exploration, and in the data-loading of geocellular models of producing oil and gas fields.

Continental shelves are affected by sea-level change, and shelf deposits are volumetrically most associated with highstand and transgressive systems tracts (Suter 2006) in seismic and sequence stratigraphic models (Vail et al. 1977; Hart et al. 2017). This is true also of the case considered here, where internal chronostratigraphic data on the Robberg spit-bar is lacking to prove that it is entirely a Holocene depositional product. Three basic models for shelf sediments exist: storm-dominated (Swift and Thorne 1991; Swift et al. 1991), tide-dominated (Dyer and Huntley 1999; Bastos et al. 2003; Li et al. 2014) or geostrophic current-dominated (Flemming 1978; Martin and Flemming 1986; Green et al., this issue), with modern continental shelves being $~ 80 \%$ storm-dominated, $\sim 17 \%$ tide-dominated, and $\sim 3 \%$ geostrophic current-dominated (Swift 1972).

The Robberg spit-bar lies in a high-energy storm-dominated region, as noted here in the section on climatology and oceanography, and with the Agulhas Current hugging the shelf/slope interface almost $100 \mathrm{~km}$ to the south. The feature (Fig. 12) comprises a large volume of medium-to-veryfine sand (Figs. 5 and 7). Sediment distribution supported by seismic images (Figs. 9 and 10) suggests a prograding upwardly coarsening sand body, attached to an older rocky headland, rather than merely associated with headlands as in the case of banner banks (e.g. Dyer and Huntley 1999). Prominent depositional features such as the Robberg spitbar therefore need to be considered in shelf facies models, and shelf oil exploration models, in particular (Nyberg and Howell 2016).

\section{Conclusions}

The findings of this study allow the following main conclusions to be drawn:

The study area can be divided into four compartments with little evidence for sediment exchange between them. The most prominent feature is a huge, headland-attached spit-bar which, stratigraphically, is composed of an upward coarsening sediment sequence that ranges from muddy fine sand at the bottom, through fine sand in the middle, to medium sand at the top.

The sediment volume in the spit-bar (compartment A) amounts to $\sim 6 \mathrm{~km}^{3}$, which stands in sharp contrast to the $0.127 \mathrm{~km}^{3}$ stored in the adjacent shoreface of compartment B.

The size and volume of headland-attached spit-bars such as the Robberg example makes them prime exploration targets for hydrocarbons in the rock record.

Supplementary Information The online version contains supplementary material available at https://doi.org/10.1007/s00367-021-00702-x.

Acknowledgements The assistance of Jack Engelbrecht, Gerry Rule, and Walter Akkers during the surveys at sea is sincerely acknowledged. Thanks are also due to the master, officers, and crew of the research vessel 'RV Meiring Naudé' for their diligent navigation and overside instrument handling. The authors also wish to acknowledge the constructive criticisms of two anonymous reviewers which served to improve the manuscript.

Funding Open Access funding enabled and organized by Projekt DEAL. The study was financed by money from the annual budget of the Marine Science Division at the Institute for Oceanology (CSIR), Stellenbosch, South Africa.

\section{Declarations}

Conflict of interest The authors declare no competing of interests.

Open Access This article is licensed under a Creative Commons Attribution 4.0 International License, which permits use, sharing, adaptation, distribution and reproduction in any medium or format, as long as you give appropriate credit to the original author(s) and the source, provide a link to the Creative Commons licence, and indicate if changes were made. The images or other third party material in this article are included in the article's Creative Commons licence, unless indicated otherwise in a credit line to the material. If material is not included in the article's Creative Commons licence and your intended use is not permitted by statutory regulation or exceeds the permitted use, you will need to obtain permission directly from the copyright holder. To view a copy of this licence, visit http://creativecommons.org/licenses/by/4.0/. 


\section{References}

Bastos AC, Kenyon NH, Collins MB (2002) Sedimentary processes, bedforms and facies, associated with a coastal headland: Portland Bill, southern UK. Mar Geol 187:235-258

Bastos AC, Collins M, Kenyon NH (2003) Morphology and internal structure of sand shoals and sandbanks off the Dorset coast, English Channel. Sedimentology 50:1105-1122

Birch GF (1980) Nearshore Quaternary sedimentation off the south coast of South Africa (Cape Town to Port Elizabeth). South African Geological Survey Bulletin 67:1-20

Birch GF, du Plessis A, Willis JP (1978) Offshore and onland geological and geophysical investigations in the Wilderness Lakes Region. Trans Geol Soc S Afr 81:339-352

Bray MJ, Carter DJ, Hooke JM (1995) Littoral cell definition and budgets for Central Southern England. J Coast Res 11:381-400

Carr AS, Bateman MD, Cawthra HC, Sealy J (2019) First evidence for onshore marine isotope stage 3 aeolianite formation on the southern Cape coastline of South Africa. Mar Geol 407:1-15. https://doi.org/10.1016/j.margeo.2018.10.0003

Carver RE (ed) (1971) Procedures in sedimentary petrology. WileyInterscience, New York, p 653

Cascalho J, Duarte J, Taborda R, Ribeiro M, Silva A, Bosnic I, Carapuco M, Lira C, Rodrigues A (2014) Sediment textural selection during sub-aerial headland bypassing - an example from the Nazaré coastal system (Portugal). Actas das 3as Jornadas de Engenharia Hidrográfica, 24-26 de junho, Lisbon, Portugal, pp 297-300

Cascalho J, Costa P, Dawson S, Milne F, Rocha A (2016) Heavy Mineral Assemblages of the Storegga Tsunami Deposit. Sediment Geol 334:21-33

Cawthra HC, Bateman MD, Carr AS, Compton JS, Holmes PJ (2014) Understanding Late Quaternary change at the land-ocean interface: a synthesis of the evolution of the Wilderness coastline, South Africa. Quat Sci Rev 99:210-223

Cawthra HC, Cowling RM, Ando S, Marean CW (2019) Geological and soil map of the Palaeo-Agulhas Plain for the last glacial maximum. Quat Sci Rev (in Press). https://doi.org/10.1016/j.quascirev. 2019.07.040

Cawthra HC, Frenzel P, Hahn A, Compton JS, Gander L, Zabel M (2020) Seismic stratigraphy of the inner to mid Agulhas Bank, South Africa. Quat Sci Rev 235:105979. https://doi.org/10.1016/j. quascirev.2019.105979

Chase BM, Meadows ME (2007) Late Quaternary dynamics of southern Africa's winter rainfall zone. Earth-Sci Rev 84:103-138

Clifton HE (1976) Wave-formed sedimentary structures - a conceptual model. In: Davis RA Jr, Ethington RL (eds) Beach and nearshore sedimentation. Society of Economic Paleontologists and Mineralogists (SEPM), Special Publication 24:126-148

Cooper JAG, Green AN, Compton JS (2018) Sea-level change in southern Africa since the Last Glacial Maximum. Quat Sci Rev 201:303-318

Cornish V (1914) Waves of sand and snow, and eddies which make them. T Fisher Unwin, London

Davies JL (1974) The coastal sediment compartment. Austr Geogr Stud 12:139-151

De Lecea AM, Green AN, Cooper JAG, Strachan KL, Wiles EA (2017) Stepped Holocene sea-level rise and its influence on sedimentation in a large marine embayment: Maputo Bay, Mozambique. Estuar Coast Shelf Sci 193:25-36

Dingle RV (1971) Tertiary sedimentary history of the continental shelf off southern Cape Province. Trans Geol Soc S Afr 74:173-186

Dingle RV, Rogers J (1972) Pleistocene palaeogeography of the Agulhas Bank. Trans Roy Soc S Afr 40:155-165

Dingle RV, Siesser WG, Newton AR (1983) Mesozoic and tertiary geology of Southern Africa. Balkema, Rotterdam
Duffy GP (2006) Bedform migration and associated sand transport on a banner bank: application of repetitive multibeam surveying and tidal current measurement to the estimated sediment transport. PhD thesis, University of New Brunswick, St. John, Canada, 209 $\mathrm{pp}$

Duffy GP, Clarke JEH, Parrott R (2004) Application of current measurement and time lapsed bathymetric multibeam surveying to investigation of Banner Bank, Mispec Bay, New Brunswick, Canada. In: Hulscher $\mathrm{S}$ et al (eds) Marine sandwave and river dune dynamics. University of Twente, The Netherlands, pp $72-79$

Dyer KR, Huntley DA (1999) The origin, classification and modelling of sand banks and ridges. Cont Shelf Res 19:1285-1330

Ferland MA (1990) Shelf sand bodies in southeastern Australia. PhD thesis, University of Sydney, Sydney, Australia, $528 \mathrm{pp}$

Field ME, Roy PS (1984) Offshore transport and sand body formation: evidence from a steep, high energy shoreface, southeastern Australia. J Sediment Petrol 54:1292-1302

Flemming BW (1978) Underwater sand dunes along the Southern African continental margin-observations and implications. Mar Geol 26:177-198

Flemming BW (1988) Process and pattern of sediment mixing in a microtidal coastal lagoon along the west coast of South Africa. In: de Boer PL, van Gelder A, Nio SD (eds) Tide-influenced sedimentary environments and facies. D Reidel Publ Co, Dordrecht, pp 275-288

Flemming BW (1998) Submerged nearshore spit bars: location, internal structure and lithology of major progradational sand bodies along the South African coast. In: Geological Society of South Africa (ed) Geocongress 98, 8-10 July 1998, Pretoria, Extended Abstracts, pp 175-177

Flemming BW (2005) The concept of wave base: fact and fiction. In: Haas H, Ramseyer K, Schlunegger F (eds) Abstracts. Sediment 2005, 18 - 20 July 2005, Gwatt, Lake Thun, Switzerland. Schriftenreihe der Deutschen Gesellschaft für Geowissenschaft 38 , p 57

Flemming BW (2015) Depositional processes in Saldanha Bay and Langebaan Lagoon (Western Cape, South Africa). National Research Institute for Oceanology (NRIO), Stellenbosch, CSIR Res Rept 362 (revised edition), 233 pp (accessible in ResearchGate)

Flemming BW, Thum AB (1978) The settling tube-a hydraulic method for grain size analysis of sands. Kiel Meeresforsch Sonderh 4:82-95

Flemming BW, Martin AK (2018) The Tsitsikamma coastal shelf, Agulhas Bank, South Africa: example of an isolated Holocene sediment trap. Geo-Mar Lett 38:107-117. https://doi.org/10. 1007/s00367-017-0507-S

Flemming BW, Martin AK, Rogers J (1983a) Onshore and offshore coastal aeolianites between Mossel Bay and Knysna. Joint GSO/ UCT Marine Geoscience Unit, Technical Report 14:151-160

Flemming BW, Eagle GA, Fricke AH, Hunter IT, Martin AK, Schumann EH, Swart VP, Zoutendyk P (1983b) Proceedings of the 7th Workshop, 2 June 1983, Stellenbosch. Agulhas Bank Studies Report No 11. National Research Institute for Oceanology Memorandum 8319

Folk RL, Ward WC (1957) Brazos River bar: a study in the significance of grain size parameters. J Sediment Res 27:3-26

Folk RL, Robles R (1964) Carbonate sediments of Isla Perez, Alacran Reef Complex, Yucatan. J Geol 72:255-292

George DA, Largier JL, Storlazzi CD, Barnard PL (2015) Classification of rocky headlands in California with relevance to littoral cell boundary delineation. Mar Geol 369:137-152

George DA, Largier JL, Storlazzi CD, Robart MJ, Gaylord B (2018) Currents, waves and sediment transport around the headland of Pt. Dume, California. Cont Shelf Res 171:63-76 
Gibbs RJ, Matthews MD, Link DA (1971) The relationship between sphere size and settling velocity. J Sediment Res 41:7-18

Goodwin ID, Freeman R, Blackmore K (2013) An insight into headland sand bypassing and wave climate variability from shoreface bathymetric change at Byron Bay, New South Wales, Australia. Mar Geol 341:29-45

Goodwin ID, Ribó M, Mortlock T (2020) Coastal sediment compartments, wave climate and centennial-scale sediment budget. In: Jackson DWT, Short AD (eds) Sandy beach morphodynamics. Elsevier, Amsterdam, pp 615-640

Guillou N, Chapalain G (2011) Effects of waves on the initiation of headland-associated sandbanks. Cont Shelf Res 31:1202-1213

Hallermeier RJ (1978) Uses for a calculated limit depth to beach erosion. Coast Eng 1:1493-1512

Hallermeier RJ (1981) A profile zonation for seasonal sand beaches from wave climate. Coast Eng 4:253-277

Hamon-Kerivel K, Cooper A, Jackson D, Sedrati M, Guisado-Pintado E (2020) Shoreface mesoscale morphodynamics: a review. Earth-Sci Rev 209:103330

Hart B, Rosen NC, West D, D'Agostino A, Messina C, Hoffman M, Wild R (eds) (2017) Sequence stratigraphy: the future defined. Society of Economic Paleontologists and Mineralogists (SEPM), Gulf Coast Section, Houston, Special Publication $36,35 \mathrm{pp}$

Hellström GB, Lubke RA (1993) Recent changes to a climbingfalling dune system on the Robberg Peninsula, southern Cape coast, South Africa. J Coast Res 9:647-653

Heydorn AEF, Tinley KL (1980) Estuaries of the Cape Part I. Synopsis of the Cape coast. Natural features, dynamics and utilization. Stellenbosch. CSIR Research Report 380

Johnson MA, Kenyon NH, Belderson RH, Stride AH (1982) Sand transport. In: Stride AH (ed) Offshore tidal sands: processes and deposits. Chapman and Hall, London, pp 58-94

Joubert JR, van Niekerk JL (2013) South African wave energy resource data-a case study. Centre for Renewable and Sustainable Energy Studies (CRSES), Faculty of Engineering, University of Stellenbosch, South Africa

Klein AHF, Vieira da Silva G, Tabords R, da Silva AP, Short AD (2020) Headland bypassing and overpassing: form, processes and applications. In: Jackson DWT, Short AD (eds) Sandy Beach Morphodynamics. Elsevier, Amsterdam, pp 557-591

Li MZ, Shaw J, Todd BJ, Kostylev VE, Wu Y (2014) Sediment transport and development of banner banks and sandwaves in an extreme tidal system: Upper Bay of Fundy, Canada. Cont Shelf Res 83:86-107

MacHutchon KR (2006) The characterisation of South African sea storms. MSc thesis, University of Stellenbosch, South Africa

Martin AK, Flemming BW (1986) The Holocene shelf sediment wedge off the south and east coasts of South Africa. In: Knight RJ, McLean JR (eds) Shelf sands and sandstones. Canadian Society of Petroleum Geologists, Memoir 11:27-44

McCarroll TJ, Masselink G, Valiente NG, Scott T, King EV, Conley D (2018) Wave and tidal controls on embayment circulation and headland bypassing for an exposed, microtidal site. J Mar Sci Eng 6:1-32

McCarroll RJ, Masselink G, Valiente NG, Scott T, Wiggins M, Kirby J-A, Davidson M (2021) A rules based shoreface translation and sediment budgeting tool for estimating coastal change: ShoreTrans. Mar Geol. https://doi.org/10.1016/j.margeo.2021.106466

McLachlan A, Illenberger WK, Burkinshaw JR, Burns MER (1994) Management implications of tampering with littoral sand sources. J Coast Res SI 12:51-59

Mendoza U, Neto AA, Abuchacra RC, Barbosa CF, Figueiredo AG, Gomes MC, Belem AL, Capilla R, Albuquerque ALS (2014) Geoacoustic character, sedimentology and chronology of a crossshelf Holocene sediment deposit off Cabo Frio, Brazil (southwest Atlantic Ocean). Geo-Mar Lett 34:297-314. https://doi.org/10.1007/ s00367-014-0370-6
Miall AD (1999) Perspectives: in defence of facies classifications and models. J Sediment Res 69:2-5

Muir RA, Bordy EM, Reddering JSV, Viljoen JHA (2017) Lithostratigraphy of the Enon Formation (Uitenhage Group), South Africa. S Afr J Geol 120:273-280

Nyberg B, Howell JA (2016) Global distribution of modern shallow marine shorelines. Implications for exploration and reservoir analogue studies. Mar Petrol Geol 71:83-104

Pingree RD, Griffiths DK (1979) Sand transport paths around the British Isles resulting from M2 and M4 tidal interactions. J Mar Biol Ass UK 59:497-513

Pretorius L, Green AN, Cooper JAG (2016) Submerged shoreline preservation and ravinement during rapid post-glacial sea-level rise and subsequent "slowstand." GSA Bull 128:1059-1069

Reading HG (1978) Sedimentary environments and facies. Blackwell, Oxford

Reading HG (1981) Clastic facies models, a personal perspective. Geol Soc Denmark Bull 48:101-115

Ribeiro M (2017) Headland sediment bypassing processes. PhD thesis, University of Lisbon, $232 \mathrm{pp}$

Rogers J (1971) Sedimentology of Quaternary Deposits on the Agulhas Bank. MSc thesis, University of Cape Town, South Africa

Rossouw J (1989) Design waves for the South African coastline. PhD thesis, University of Stellenbosch, South Africa

Roy PS, Cowell P, Ferland M, Thom B (1994) Wave-dominated coasts. In: Carter RWG, Woodroffe CD (eds) Coastal evolution-late Quaternary shoreline morphodynamics. Cambridge University Press, Cambridge, pp 121-186

Schumann EH, Perrins L-A, Hunter IT (1982a) Upwelling along the South Coast of the Cape province, South Africa. S Afr J Sci 78:238-242

Schumann EH, Flemming BW, Swart VP, Hunter IT (1982b) Agulhas Bank Studies Report No. 8: report on measurement programmes 20 January to 22 March 1982. NRIO (CSIR) Memorandum 8, 39 pp

Selley RC (1995) Ancient sedimentary environments and their sub-surface diagnosis. Routledge, London

Short AD (2020) Australian coastal systems: beaches, barriers and sediment compartments. Coastal Research Library 32. Springer Nature Switzerland, Cham

Signell RP, Harris CK (2000) Modelling sand bank formation around tidal headlands. In: Spaulding ML, Blumberg AF (eds) Proceedings of the 6th International Conference on Estuarine and Coastal Modelling, 3-5 November 1999, New Orleans. ASCE, Reston, pp 209-222

Suter JR (2006) Facies models revisited: clastic shelves. In: Posamentier HW, Walker RG (eds) Facies models revisited. SEPM Spec Publ 84:339-397

Swift DJP (1972) Implications of sediment dispersal from bottom current measurements; some specific problems in understanding bottom sediment distribution and dispersal on the continental shelf: a discussion of two papers. In: Swift DJP, Duane DB, Pilkey OH (eds) Shelf sediment transport: process and pattern. Dowden, Hutchinson and Ross, Stroudsburg, pp 363-371

Swift DJP, Thorne JA (1991) Sedimentation on continental margins, 1: a general model for shelf sedimentation. In: Swift DJP, Oertel GF, Tillman RW, Thorne JA (eds) Shelf sand and sandstone bodies: geometry, facies and sequence stratigraphy. IAS Spec Publ 14:1-31

Swift DJP, Oertel GF, Tillman RW, Thorne JA (eds) (1991) Shelf sand and sandstone bodies: geometry, facies and sequence stratigraphy. IAS Spec Publ 14, Blackwell, Oxford

Thom BG, Eliot I, Eliot M, Harvey N, Rissik D, Sharples C et al (2018) National sediment compartment framework for Australian coastal management. Ocean Coast Manag 154:103-120

Toerien DK (1976) Geology of the Tsitsikamma coastal area (in Afrikaans). Koedoe 19:31-41

Truc L, Chevalier M, Favier C, Cheddadi R, Meadows ME, Scott L, Carr AS, Smith GF, Chase BM (2013) Quantification of climate change 
for the last 20,000 years from Wonderkrater, South Africa: implications for the long-term dynamics of the Intertropical Convergence Zone. Palaeogeogr Palaeoclim Palaeoecol 386:575-587

Tyson PD, Preston-Whyte R (2000) The weather and climate of southern Africa. Oxford University Press, Cape Town

Vail PR, Mitchum RM, Todd RG, Widmer JM, Thompson S, Sangree JB, Burr RG, Hatfield WG (1977) Seismic stratigraphy and global changes of sealevel. In: Payton CE (ed) Seismic stratigraphy: application to hydrocarbon exploration. American Association of Petroleum Geologists, Memoir 26:49-212

Vieira da Silva G, Toldo EE Jr, Klein AHF, Short AD, Woodroffe AD (2016) Headland sand bypassing-quantification of net sediment transport in embayed beaches, Santa Catarina Island north shore, southern Brazil. Mar Geol 329:13-27

Vieira da Silva G, Toldo EE Jr, Klein AHF, Short AD (2018) The influence of wave-, wind- and tide-forced currents on headland sand bypassing-study case: Santa Catarina Island north shore, Brazil. Geomorphology 312:1-11

Walger E (1962) Die Korngrößenverteilung von Einzellagen sandiger Sedimente und ihre genetische Bedeutung. Geol Rundschau 51:494-507

Wentworth CK (1922) A scale of grade and class terms for clastic sediments. J Geol 30:377-392

Publisher's note Springer Nature remains neutral with regard to jurisdictional claims in published maps and institutional affiliations. 